\title{
The Concept of Sustainable Development in Global Law: Problems and Perspectives
}

\author{
By Giulia Capitani* \\ Giovanni Comazzetto ${ }^{\dagger}$
}

The aim of this paper is to focus on the multidimensional aspect of sustainable development and on the legal implications. Although in 1987 sustainable development was defined by the United Nations Environment Programme as "development that meets the needs of the present without compromising the ability of future generations to meet their own needs", nowadays it lacks a more precise legal definition; therefore, legislators struggle to implement it effectively. Law should identify an adequate balance between all the different interests involved, which are the expression of the interdependence between social and economic development and environmental protection. This fascinating concept has passed from the ethics field to the legal field, and, as a global issue, it has caused interactions between international, European and national law. This process started in international context (starting from the Declaration of the United Nations Conference on the Human Environment in 1972), then in EU law (art. 2 TEEC, art. 1 European Landscape Convention 2000). Even if the concept of sustainable development has been included in many constitutions around the world, the lack of a precise legal definition makes it difficult to find the right balance point to identify a kind of development that can satisfy the necessities of human society. In our paper we propose to follow a two-step approach. Firstly, we will describe the evolution of the concept of sustainable development in the intersection of diverse rules stemming from different legal orders and the types of coordination between the different levels. Then we will analyse the potential synergies between these overlapping regulatory systems, in order to achieve a high level of protection for the environment as a whole and to ensure a better future to the present and new generations.

Keywords: Constitution; Globalization; Environmental Protection; International Law; Sustainable Development.

\section{Introduction}

The scale of human development on the natural world has been a cause of widespread concern that has progressively led to consider environmental protection as an ethical value. With the continuing evolution of technologies, nowadays environmental issues as sustainable development, its core principle, are at the top of international and domestic political agenda as a new field of academic enquiry from different perspectives (natural sciences, economics, politics, law, etc.). Since it clearly emerges as a priority issue of global dimension, a multilateral

\footnotetext{
${ }^{*} \mathrm{PhD}$ Candidate in Constitutional Law, University of Padua, Department of Public, International and Community Law, Padua, Italy. Email: giulia.capitani@phd.unipd.it.

${ }^{\dagger} \mathrm{PhD}$ Candidate in Constitutional Law, University of Padua, Department of Public, International and Community Law, Padua, Italy. Email: giovanni.comazzetto@phd.unipd.it.
} 
and transnational approach is needed. As a part of this holistic strategy, law plays an essential role in the pursuit of environmental protection and in the promotion of sustainable development, imposing effective obligations on States. Simultaneously, law could be considered as an instrument to impose certain ethical values, forming the framework in which ethical perspectives can operate to find a better governance of this contemporary, technological and complex society. The achievement of this target requires a radical reinterpretation of development ${ }^{1}$. This paper explores how the concept of Sustainable Development has evolved over the last decades, starting from the first treaties on environmental protection. It is divided into three sections. The first section looks at the evolution of the concept of sustainable development in international and European law. Section 2 sketches the international legal framework emerging from the Paris Agreement and the 2030 Agenda, in the light of the concept of sustainable development. The last section is devoted to examining the adequacy of this conceptual framework, in order to address the threat of an ecological catastrophe.

\section{The Evolution of the Concept of Sustainable Development}

\section{The Concept of Sustainable Development in International Law}

The consequences of the growing environmental impact of human development on nature progressively led to consider environmental protection as an ethical value.

The environmental issues are global issues and they do not respect borders, so the evolution of the concept of sustainable development started in the field of international law, with the awareness that no country can resolve global challenges by acting alone.

Nowadays we can consider in the same way economic and financial issues that are becoming global issues for the creation of a common economic space in which the economic instability of a country, due to a butterfly-effect, can cause a crisis in the global economy, as it happened in $2008^{2}$.

In 1968 the no profit association "Club of Rome" was founded by Aurelio Peccei with the aim to analyse the principle problems of humanity in a global context. It was the first international forum to deal with issues about the growth of population and its impact on the world. The first and most famous Report commissioned by the Club of Rome was "The limits to growth", research team of MIT and published in 1972, regarding the effects of the increase of population on the environment and on human survival. According to this report, if the growth trends and the consequent exploitation of natural resources without limit continued as was the case in 1972, there would be environmental degradation, leading to "sudden and uncontrollable decline in both population and industrial

\footnotetext{
${ }^{1}$ Gupta \& Arts (2018).

${ }^{2}$ Porena (2017) at 101.

${ }^{3}$ Meadow, Meadow, Randers \& Behrnes (1972).
} 
capacity" in the next 100 years. So the report revealed the necessity of a sustainable ecological and economic stability.

Despite initial criticisms, this work highlighted for the first time the urgency to face environmental issues and the influence of economic development on environmental degradation. So, in 1970, the awareness of the necessity of a multilateral and transnational approach to tackle environmental issues started to emerge and was accompanied with the concern for the future generations.

In 1972 the Declaration of the United Nations Conference on the Human Environment signed the first step in the evolution of the concept of sustainable development in the legal field. The Declaration was adopted during an international Conference, held in Stockholm, in which countries agreed on the necessity of a common outlook and for common principles to inspire and guide the world in the preservation and enhancement of the human environment.

In particular, the first principle of the Declaration establishes that: "Man has the fundamental right to freedom, equality and adequate conditions of life, in an environment of a quality that permits a life of dignity and well-being, and he bears a solemn responsibility to protect and improve the environment for present and future generations. In this respect, policies promoting or perpetuating apartheid, racial segregation, discrimination, colonial and other forms of oppression and foreign domination stand condemned and must be eliminated". This principle expresses a responsibility of the present generations towards future generations, but it doesn't yet formulate the concept of sustainable development.

Also, in the Declaration the growth of population and its impact for the preservation of the environment is considered. People in propelling social progress, creating social wealth, developing science and technology, continuously transform the human environment, so the adoption of adequate policies and appropriate measures are necessary to face this problem.

The concept of sustainable development implies the protection of the future generations, but for an accredited definition of sustainable development we had to wait until 1987. In this year the Report "Our Common Future" of World Commission on Environment and Development (so called Brundtland Report in recognition of former Norwegian Prime Minister Gro Harlem Brundtland's role as Chair of the World Commission on Environment and Development), was published, in which sustainable development was defined as "development that meets the needs of the present without compromising the ability of future generations to meet their own needs"4.

This is the first and the most accredited definition of sustainable development and links the two concepts of development and protection of the future generations, highlighting their interdependence.

The definition contains two key elements: the necessity of taking into account the needs of present and future generations, in particular the essential needs of the world's poor, to which overriding priority should be given; and the idea of limitations imposed by the state of technology and social organization on the environment's ability to meet present and future needs ${ }^{5}$.

\footnotetext{
${ }^{4}$ World Commission on Environment and Development (1987) at 16.

${ }^{5}$ Idem: "The concept of sustainable development does imply limits - not absolute limits but
} 
In the definition there isn't any reference to the environment, although it is well known that the concept of sustainable development had started to evolve in the field of environmental issues. The definition adopted by the United Nations Environment Programme increases the concern for the needs of future generations beyond the concept of environmental preservation, including political and social issues and this trend was followed by other international documents.

Another fundamental step in the evolution of the concept of sustainable development was represented by the United Nation Conference on Environment and Development, also known as the Rio de Janeiro Earth Summit, held in 1992. During this international conference "Rio Declaration on Environment and Development", which consists of 27 principles to achieve sustainable development, and the Agenda 21, a non-binding action plan, were adopted. These non-binding acts are considered as important achievements in the evolution of the concept of sustainable development.

In the principle n. 5 of the "Rio Declaration of Environment and Development" is established that "all States and all people shall co-operate in the essential task of eradicating poverty as an indispensable requirement for sustainable development, in order to decrease the disparities in standards of living and better meet the needs of the majority of the people of the world", whereas the principle n. 8 identifies sustainable patterns of production and consumption and appropriate demographic policies as measures to achieve sustainable development, extended this concept even beyond the environmental issues.

So this concept progressively affirms a responsibility among the present generations, which is logically derived from the proclamation of the responsibility towards future generations. Although the Rio Declaration does not refer by name to any concept of intra-generational equity, several of its substantives provisions

\footnotetext{
limitations imposed by the present state of technology and social organization on environmental resources and by the ability of the biosphere to absorb the effects of human activities. But technology and social organization can be both managed and improved to make way for a new era of economic growth. The Commission believes that widespread poverty is no longer inevitable. Poverty is not only an evil in itself, but sustainable development requires meeting the basic needs of all and extending to all the opportunity to fulfil their aspirations for a better life. A world in which poverty is endemic will always be prone to ecological and other catastrophes. 28. Meeting essential needs requires not only a new era of economic growth for nations in which the majority are poor, but an assurance that those poor get their fair share of the resources required to sustain that growth. Such equity would be aided by political systems that secure effective citizen participation in decision making and by greater democracy in international decision making. 29. Sustainable global development requires that those who are more affluent adopt life-styles within the planet's ecological means - in their use of energy, for example. Further, rapidly growing populations can increase the pressure on resources and slow any rise in living standards; thus sustainable development can only be pursued if population size and growth are in harmony with the changing productive potential of the ecosystem. 30. Yet in the end, sustainable development is not a fixed state of harmony, but rather a process of change in which the exploitation of resources, the direction of investments, the orientation of technological development, and institutional change are made consistent with future as well as present needs. We do not pretend that the process is easy or straightforward. Painful choices have to be made. Thus, in the final analysis, sustainable development must rest on political will".
} 
imply that intra-generational concerns represent a fundamental element in the contemporary development of international environmental law ${ }^{6}$.

The concept of sustainable development has shifted to focus more on economic development and social development and the concern for future generations, issues that are linked to the environmental protection. In this holistic approach, the consideration for the carrying capacity of natural systems is connected with the social, political and economic challenges of our time. The concept of sustainability can be expressed by using a three pillar model: environment dimension (intergenerational equity), social dimension (intergenerational equity), and economic dimension; these dimensions have to be considered in an equal way to achieve sustainable development ${ }^{7}$.

Therefore, the concept presents a multidisciplinary character, because it is composed of various aspects and we can find references to the principle in different legal sources, but, from a pragmatic point of view, we must recognize the presence of a certain vagueness which affects the correct application of the principle $^{8}$.

On one hand the concept of sustainable development is like a point of balance, it must be flexible and reach the best settlement among opposed interests, on the other this flexible and multidisciplinary character makes it difficult to create effective obligations on States and consequently to implement the principle, relegating sustainable development in the field of ethical values.

The legal status of this concept is controversial, part of the doctrine recognizes sustainable development already as a principle of international law, and for some scholars it even represents the formation of a new branch of law ${ }^{9}$, but for other scholars sustainable development is still an ethical value ${ }^{10}$. Probably the concept could be better understood as a general guideline to policy action. ${ }^{11}$

\section{The Concept of Sustainable Development in European Union Law}

In the European Union Law the operational nature of the concept is particularly enhanced. Intact, sustainable development is listed among the goals to achieve and it is considered as a legally binding objective that the policies of the European Union have to pursue, from the adoption of the Amsterdam Treaty

\footnotetext{
${ }^{6}$ Birnie \& Boyle (2002) at 91: The Principle n. 3 of the Rio Declaration establishes that "the right to development must be fulfilled so as to equitably meet developmental and environmental needs of present and future generations". The principle n. 22 declares that "Indigenous people and their communities, and other local communities, have a vital role in environmental management and development because of their knowledge and traditional practices" and establishes that "States should recognize and duly support their identity, culture and interests and enable their effective participation in the achievement of sustainable development". The principle n. 23 declares that "the environment and natural resources of people under oppression, domination and occupation shall be protected" whereas the principle n. 25 underlines that "peace, development and environmental protection are interdependent and indivisible".

${ }^{7}$ Kerschner \& Wagner (2016) at 60.

${ }^{8}$ Kramer (2002) at 71.

${ }^{9}$ Atapattu (2006) at 194; Fracchia (2010) at 259.

${ }^{10}$ Dell'Anno (2004) at 75.

${ }^{11}$ Brownlie (2008) at 278-279.
} 
in 1997, which introduced the concept into article 2 and article 6 of the Treaty establishing the European Economic Community ${ }^{12}$. It was underlined that there was a slight time lag between the recognition of sustainable development at the international level and its emergence in the political discourse of the European Communities. In fact, it was only ten years after the Brundtland Report, that sustainable development was legally recognized in the Treaties with the Treaty of Amsterdam ${ }^{13}$.

The concept was included in the Treaties together with the other provisions on the environment. This consideration signals "the commitment to ensure a prudent use of natural resources in order to take the environmental and economic interests of future generations, as those of the present ones, into account"14.

Another consideration to underline is that "sustainable development" is also defined as a principle and not a concept. Although the controversies in the doctrine about whether sustainable development is an inspiring ethical concept or a solid legal principle, the inclusion of the concept among the "principles" may denote that in the European Union Law sustainable development is consolidated as a principle $^{15}$.

There is no legal definition of the concept in the European Union system, which follows in this matter the definition provided by the Report "Our Common Future".

The term sustainable development has also been introduced into the preamble and in the article 37 of the European Union Charter of Fundamental Rights, which establishes that "a high level of protection and improvement of the quality of the environment must be integrated into the Union's policies and ensured in accordance with the principle of sustainable development". This provision doesn't grant a "real" fundamental right to single persons, but rather proclaims a general duty of the EU and the Member States to take into account environment protection in their policies ${ }^{16}$.

In the European Union Law sustainable development is closely related to another fundamental principle: the general integration principle, embodied in Art. 11 of the Treaty on Functioning of the European Union (TFEU). In particular, the article imposes that "environmental protection requirements must be integrated into the definition and implementation of Community policies and activities, in particular with a view to promoting sustainable development".

In June 2001, at the Göteborg Summit, the first European Union Sustainable Development Strategy was adopted. The Strategy, composed of two main parts, identified objectives and policy measures to face a number of key unsustainable trends and called for a new approach to policy-making that ensures the EU's economic, social and environmental policies mutually reinforced each other. The Göteborg Declaration is the core of the EU's policies towards sustainable

\footnotetext{
${ }^{12}$ Kenig-Witkowska (2017) at 67.

${ }^{13}$ Pallemaerts \& Azmanova (2006) at 20.

${ }^{14}$ Kramer (2000) at 7.

${ }^{15}$ Mahmoudi (2000) at 125.

${ }^{16}$ Kerschner \& Wagner (2016) at 58.
} 
development. These policies also include the global pledge made at the 2002 World Summit on Sustainable Development in Johannesburg and the Millennium Development Goals agreed in 2000.

The first EU Sustainable Development Strategy establishes overall objectives and concrete actions for seven key priority challenges for the period until 2010: 1) climate change and clean energy; 2) sustainable transport; 3) sustainable consumption and production; 4) conservation and management of natural resources; 5) public health; 6) social inclusion, demography and migration; 7) global poverty and sustainable development challenges.

Despite important achievements in implementing the Strategy, the persistence of unsustainable trends required a new Sustainable Development Strategy.

In June 2005, the European Council adopted the "Declaration on the guiding principles for sustainable development" designed to give new life to the European Union's commitment to sustainable development. The notion of sustainable development is not explicitly defined by the European Council's declaration, but this document structures a comprehensive vision of the concept, which the Commission describes as a "broad long-term vision of sustainability". In particular, the Declaration establishes that "Sustainable Development is a key objective for all European Community policies, set out in the Treaty. It aims at the continuous improvement of the quality of life on earth of both current and future generations. It is about safeguarding the earth's capacity to support life in all its diversity. It is based on the principles of democracy and the rule of law and respect for fundamental rights including freedom and equal opportunities for all. It brings about solidarity within and between generations. It seeks to promote a dynamic economy with a high level of employment and education, of health protection, of social and territorial cohesion and of environmental protection in a peaceful and secure world, respecting cultural diversity" (Communication from the Commission to the Council and the European Parliament - Draft Declaration on Guiding Principles for Sustainable Development, COM/2005/0218 final).

To achieve these aims in Europe the European Union defines "key objectives" to pursue and respect. These objectives represent long-term aims reflecting the three pillars of sustainable development: environmental protection, social equity and cohesion and economic prosperity. "The guiding principles include a number of principles related to democracy, solidarity and good governance (promotion and protection of fundamental rights, citizen and stakeholder participation, access to information and justice, intra-generational and intergenerational solidarity, policy coherence, use of best available knowledge) combined with some of the basic principles of EU environmental policy (precautionary principle, integration, and the polluter pays principle). None of these principles really breaks new ground; it is their combination in a single document under the heading of sustainable development, and the Commission's assertion that they «correspond to the underlying values of a dynamic European model of society», which are noteworthy"17.

Furthermore, these policy-making documents constitute legal basis for the EU legally binding acts.

\footnotetext{
${ }^{17}$ Pallemaerts \& Azmanova (2006) at 48.
} 
In December 2005 the Commission presented a proposal for a reviewed Strategy and platform for further action based on the 2001 Strategy. Subsequently, at the European Council in June 2006, the renewed Strategy for an enlarged EU was adopted. The main purpose of the Strategy was to move towards a better integrated approach to policy-making.

The European Commission adopted in October 2007 the first progress report on the Sustainable Development Strategy. According to the report, there have been significant policy developments in some of the seven key priorities identified in the reviewed Strategy of 2006, but progress on policy has not yet translated into substantial concrete action. In December 2007, the European Council stressed that the main focus should be on effective implementation at all levels of the renewed Strategy (Presidency conclusions, Brussels European Council, 14 December 2007).

In the last ten years the EU has taken the lead in the fight against climate change and the promotion of low-carbon economy.

In 2009, the Commission adopted the Review of EU Sustainable Development Strategy, confirming that "sustainable development is set out in Article 3(3) (TEU) of the new Treaty as an overarching and long-term goal of the EU. The EU Sustainable Development Strategy (SDS) is a framework for a long-term vision in which environmental protection, economic prosperity, social cohesion and global responsibility are mutually supportive" (Council of the European Union, Presidency Report on the 2009 Review of the EU Sustainable Development Strategy, 2009). The Commission also underlined that urgent actions are needed to prevent the climate change, to decrease high - energy consumption in the transport sector and reverse the current loss of biodiversity and natural resources. Priority actions should be more clearly specified in future reviews.

The new EU 2020 Strategy on sustainable development, adopted in 2010, contributed to moving Europe out of the crisis and laying the foundations for a more sustainable future, based on smart, sustainable and inclusive growth. The Commission proposed five measurable EU targets for 2020 to steer the process and to be translated into national targets related to five critical areas: employment, research and innovation, climate change and energy, education and fight against poverty (Communication from the Commission "Europe 2020. A Strategy for smart, sustainable and inclusive growth", COM (2010) 2020, 2010).

\section{The Concept of Sustainable Development in Constitutional Law}

In 54 Constitutions around the world a reference about sustainability or about the principle of sustainable development is included, while in 69 Constitutions the concern of future generations is contained and, in the majority of these, it is related to the environmental protection. These provisions, as the definition of sustainable development in the field of international law, are vague and general, so also in the field of constitutional Law emerges the need of a legislative $o$ judicial implementation $^{18}$.

\footnotetext{
${ }^{18}$ Groppi (2016) at 43.
} 
Even if the concept of sustainable development has been included in many legal sources, the lack of a precise legal definition makes it difficult to find the right balance point to identify a kind of development that can satisfy the necessities of human society, also we have to consider that authority is often divided between several levels of government, including local government with considerable independence and self-determination.

Law could be considered as an instrument to impose certain ethical values, forming the framework in which ethical perspectives can operate to find a better governance of this complex society and its role could be fundamental to reach a fair balance of interests among so many disciplines and actors dealing with sustainable development. Nowadays legislators struggle to implement the concept of sustainable development effectively and to bring it to the centre of decision making ${ }^{19}$.

A solution to achieve effectivity could be found by including binding procedural provisions in the Constitutions, aimed at integrating sustainability instances into decision making, to ensure the protection of the future generations, who have no voice to be heard.

The Concept of Sustainable Development in the International Agreements on Climate Action

The events surrounding international climate negotiations of the past 20 years have shown the difficulty of achieving a broad consensus on collaborative actions against climate change. The Kyoto Protocol was an international treaty that committed state parties to reduce greenhouse gas emissions; it was adopted in 1997 and entered into force in 2005. It was based on the principle of common but differentiated responsibilities, because individual countries have different capabilities in combating climate change, owing to economic development; it put the obligation to reduce current emissions on developed countries on the basis that they are historically responsible for the current levels of greenhouse gases in the atmosphere. According to the Kyoto Protocol only 37 countries had binding targets. Sustainable development was mentioned in Article 2 of the Protocol, as the aim of the gas emission reduction. The Kyoto Protocol did not offer a satisfactory solution to the problems encountered: it failed because some States (such as the USA) refused to ratify the Protocol, and others (China, India and the rest of the developing countries) were not bounded at all. More generally, the problem with the Kyoto Protocol was that it "subjected the world to an ineffective pathdependent model for solving climate change" 20 .

The Paris Agreement, which was adopted on 12 December 2005, marks a significant departure from the Kyoto Protocol and also from many other international agreements on climate change. It is the world's first comprehensive climate agreement, and it aims to strengthen the global response to the threat of climate change by holding the increase in the global average temperature to well below $2^{\circ} \mathrm{C}$ above pre-industrial levels and pursuing efforts to limit the temperature

\footnotetext{
${ }^{19}$ Salardi (2011) at 79.

${ }^{20}$ Rosen (2015).
} 
increase to $1.5^{\circ} \mathrm{C}$ above pre-industrial levels. In order to achieve the greatest possible consensus, the Paris Agreement abandons the Kyoto Protocol's dualistic scheme. As a result, it does not impose legally binding targets: each Party "shall prepare, communicate and maintain successive nationally determined contributions that it intends to achieve" (Paris Agreement, Article 4.2). Is it only "soft law"? Can a Party downgrade its nationally determined contribution (NDC) to climate mitigation without violating its Treaty obligations? This is a legal question that generated much debate when President Trump decided to dismantle Obama-era domestic regulations designed to address US greenhouse gas emissions well in advance of the withdrawal decision. Some scholars think that while national contributions as such are not legally binding, they are subject to binding procedural requirements and to normative expectations of progression and highest possible ambition. Read together, these binding and non-binding terms make it clear that a Party would contravene the spirit of the Paris Agreement if it downgraded an existing national determined contribution (Rajamani and Brunnée, 2017).

The Paris Agreement's Preamble refers to the "intrinsic relationship that climate change actions, responses and impacts have with equitable access to sustainable development" (italics added), but it also clarifies that Parties should "respect, promote and consider their respective obligations on human rights, [...] and the right to development". The 2030 Agenda for Sustainable Development (hereinafter "2030 Agenda"), which must be read in conjunction with the Paris agreement, claims that the Sustainable Development Goals and targets are "integrated and indivisible, global in nature and universally applicable, taking into account different national realities, capacities and levels of development and respecting national policies and priorities" (2030 Agenda, 55).

\section{Towards a Reconciliation of Sustainable Development and Right to Development: A Concrete Utopia?}

This tension between the "right to development" and the "right to promote sustainable development" was already present, in nuce, in the United Nations Framework Convention on Climate Change (UNFCCC). In 1992, while the developing countries wanted to include the Right to Development and objected to sustainable development as a new conditionality, industrialized countries supported the Right to Promote Sustainable Development. So there are two different rights, the right to development and the right to promote sustainable development - which is also a duty.

The right to development is very important for developing countries in the post-colonial order, because the collective efforts required for realizing the $1.5{ }^{\circ} \mathrm{C}$ objective could have negative repercussions for their economic systems. Their development prospects could be affected negatively by international law. So they have every reason to ask for a redistribution of international resources, and to take into consideration past colonial injustices.

In order to address this legitimate request, the more developed countries can't consider their right to development as the right to full sovereignty over all natural 
wealth and resources. The Right to Promote Sustainable Development pursues sustainable development which calls for considering economic, social and ecological aspects and reconciling the rights of current and future generations. It establishes at the very least that it is legitimate for states to promote sustainable development. One step further than this would be to recognise a right to progressively achieving sustainable development. While this right by no means has crystalized fully in current international law, it might be a prelude of a season of reforms of old codifications of international law norms and obligations, in the light of sustainable development impact assessments, and it might call for applying sanctions or trade incentives to promote sustainable development ${ }^{21}$. Moreover, we have to create a framework unifying the right to development and the right to promote sustainable development. We need a radical redefinition of development, in order to create an "integrated concept". Climate change is now undeniably one of the greatest challenges facing humanity: we can face this tremendous challenge only if we learn to strike the right balance between economic growth and respect for the environment.

According to the IPCC's (Intergovernmental Panel on Climate Change) latest report, from 1880 to 2012 average global temperature increased by $0.85{ }^{\circ} \mathrm{C}$. Oceans have warmed, sea level has risen. The best case scenario currently possible to us is an increase of $1.7{ }^{\circ} \mathrm{C}$ by the end of the century and requires that we immediately decrease $\mathrm{CO} 2$ emissions by 2100 . This means that in order to see a max temperature increase of $1.7^{\circ} \mathrm{C}$, all of our energy must come from carbon-free sources by 2100 . The current emissions path that we are on corresponds approximately to a global surface temperature increase of about $4.8^{\circ} \mathrm{C}$ and a sea level rise of about 1 meter by 2100 .

Despite its shortcomings, the Paris Agreement is a considerable improvement when compared with the Kyoto Protocol. But there is still a long way to go. On the one hand, we need stronger obligations on the international level; on the other hand, we must conceive new forms of global cooperation, which do not depend on the market or on diplomatic negotiations. And the first lesson to consider is the one repeatedly made by Stephen Jay Gould: the utter contingency of our existence ${ }^{22}$.

\section{References}

Atapattu S.A. (2006). Law Emerging Principles of International Environmental. Transnational Publishers.

Birnie P. \& A. Boyle (2002). International Law \& the environment. Oxford University Press.

Brownlie, I. (2008). Principles of Public International Law. Oxford University Press.

Dell'Anno, P. (2004). Principi del diritto ambientale europeo e nazionale, Giuffrè..

Fracchia, F. (2010). Lo sviluppo sostenibile. Editoriale Scientifica.

Groppi, T. (2016). 'Sostenibilità e costituzioni: lo Stato costituzionale alla prova del futuro' in Diritto pubblico comparato ed europeo, 1/2016:43 - 78.

\footnotetext{
${ }^{21}$ Gupta \& Arts (2018).

${ }^{22}$ Žižek (2009).
} 
Gupta, J. \& K. Arts (2018). 'Achieving the $1.5^{\circ} \mathrm{C}$ objective: just implementation through a right to (sustainable) development approach' in International Environmental Agreements: Politics, Law and Economics 18(1):11-28. Available also at: https://link. springer.com/10.1007/s10784-017-9376-7

Kenig-Witkowska, M. (2017). 'The Concept of Sustainable Development in the European Union Policy and Law' in Journal of Comparative Urban Law and Policy 1(1):6480. Available also at https://readingroom.law.gsu.edu/jculp/vol1/iss1/6

Kerschner, F. \& E. Wagner (2016). 'Sustainability - A Long, Hard Road' in V. Mauerhofer (ed.) Legal Aspects of Sustainable Development - Horizontal and Sectorial Policy Issues. Switzerland: Springer. Pp. 57- 78.

Kramer L. (2000). EC Environmental Law. Sweet \& Maxwell.

Kramer L. (2002). Manuale di diritto comunitario per l'ambiente. Giuffrè.

Mahmoudi, S. (2000). 'Protection of the European Environment after the Amsterdam Treaty' in Scandinavian studies in law 39:123 - 137. Available also at: http://www. scandinavianlaw.se/pdf/39-8.pdf

Meadows, D. H., Meadows, D. L., Randers, J. \& III W.W. Behrens (1972). The limits to Growth - A Report to the Club of Rome's Project on the

Predicament of Mankind. New York: Universe Books.

Montini, M. (2016). 'Riflessioni critiche sull'Accordo di Parigi sui cambiamenti climatici' in Rivista di Diritto Internazionale 100(3):719-755.

Nespor, S. (2016). 'La lunga marcia per un accordo globale sul clima: dal Protocollo di Kyoto all'Accordo di Parigi' in Rivista Trimestrale di Diritto Pubblico 1: 81-121. Available also at http://www.nespor.it/wp-content/uploads/2016/04/ACCORDO-DIPARIGI-FINALE-PER-RTDP.pdf

Pallemaerts, M. \& A. Azmanova (eds.) (2006). The European Union and Sustainable Development: Internal and external dimensions. Brussels, Belgium: VUB Press.

Porena D. (2017). Il principio di sostenibilità. Contributo allo studio di un programma costituzionale di solidarietà intergenerazionale. Torino: Giappichelli,

Rajamani, L. \& J. Brunnée (2017). 'The Legality of Downgrading Nationally Determined Contributions under the Paris Agreement: Lessons from the US Disengagement' in Journal of Environmental Law 29:537-551. Available also at https://academic.oup. com/jel/article/29/3/537/4318807

Rosen, A.M. (2015). "The Wrong Solution at the Right Time: The Failure of the Kyoto Protocol on Climate Change" in Politics \& Policy 43(1):30-58. Available also at https://onlinelibrary.wiley.com/ doi/pdf/10.1111/polp.12105

Salardi, S. (2011). 'Sustainable development: Definitions and Models of legal regulation. Some legal-theoretical outlines on the role of law' in Rivista quadrimestrale di diritto dell'ambiente 2011(1):76 - 99.

World Commission on Environment and development (1987). Our common future. Oxford New York: Oxford University Press.

Žižek, S. (2009). In Defense of Lost Causes. London New York: Verso. 